\title{
Tax Problems in the Trademark and Trade Name Field
}

\author{
Adrian A. Kragen* and Samuel F. Pearce ${ }^{\dagger}$
}

There is no paucity of decisions or erudite writing in the general field of trademark and trade name law. However, when attention is directed to that comparatively new Frankenstein of the law, taxation, in its application to trademarks and trade names, the situation is entirely different. ${ }^{1}$ Although every volume of the Federal Reporter and Supplement contains a myriad of cases, and professors and lawyers vie in the annual production of tax articles, there is only infrequent, brief reference to trademarks and trade names; there is apparently but one article and a single monograph dealing specifically with this area. ${ }^{2}$ Until 1955 even Mertens, the authoritative text on income tax, dealt with these problems only casually or inferentially.

\footnotetext{
* Professor of Law, University of California, Berkeley.

$\uparrow$ Member, State Bar of California; Associate in Law 1955-56, University of California, Berkeley.
}

1 Although this discussion is limited to the impact of federal tax laws in the trademark and trade name field, the possibility of a property tax impact should not be wholly ignored. Only one case dealing directly with the problem could be found; it beld that a trademark was not property in the sense intended by the particular statute because the mark had no intrisic value. Commonwealth v. Kentucky Distilleries \& Warehouse Co., 132 Ky. 521, 116 S.W. 766 (1909). If this is so, the mark may still be taxable under the type statute found in Florida in which intangible personal property is defined as "all personal property which is not in itself intrinsically valuable but which derives its value fron that which it represents." FLA. STat. § 199.01 (1955). Most states limit their tax on intangibles to written evidences of debt and the like. Cf. Car. Rev. \& TAX. Code $\$ 111$; Mich. Conrp. Laws $\$ 205.131$ (b) (1948); Kan. Gen. Stat. ANv. $\$ 79-3108$ (1949). Of course, there is the obvious difficulty of making a value determination in the case of the trademark unless it has been the subject of a sale, but if the tax statute of a state is of the same general type as that of Florida, the valuation obstacle should not be insurmountable so far as taxing authorities are concerned. $C f$. Sanderfur v. Beard, 249 S.W. 274, 275 (Tex. Civ. App. 1923) (court found "goodwill" as taxable as any other property if the value could be ascertained). At a time when states search for additional revenue, the income potential of taxing such a valuable intangible could be realized at any time.

2 Soper, Certain Accounting and Tax Aspects of Trade Marks, 44 Trade-Mark Rep. 1 (1955). As the title indicates the author approaches the problem fron the accountant's viewpoint, though he lays some legal foundation for his comments. GITIIN AND WOODWARD, TAX Aspects of Patents, Copyrights and Trade-Marks (1954). The authors concentrate principally on the patent and copyright problems; however, their background material on the nature of the rights involved in any discussion of trademarks and trade names provides a good starting point for those who may be unfamiliar with this particular field of the law.

3 Prior to the 1954 revision of volume four the major discussion of the tax problems in trademarks and trade names was included in the sections on deduction for depreciation of goodwill, 4 MERTENs, Law of FeDERAI. INcone Taxation \$\$ 23.117-19 (1942), and deduction of business expense, id. $\S 25.24$. In the 1954 revision more direct treatment is accorded tradeinarks and trade names in the explanation of INT. REv. CODE OF 1954 \$ 174. 4 MERTENS, LAw of Federat Income TaxatTon $\$ \$ 25.30-34$ (1954). 
Possibly this poverty of treatment can be attributed to the fact that the development of trademarks and trade names is so inextricably tied to all phases of busmess operation and industrial growth that the tax considerations, which normally play a major business role, are lost as an integral part of the general treatinent of goodwill, capital acquisition, business expense and the like.

One can surmise that the average industrialist who certainly recognizes the value of the trademark he has built into nationwide acceptance has no conception of the treatment of that mark or name for tax purposes. Asked to estimate its tax basis, he would probably name a large sum; yet his books may, and his tax return certainly would, show a tax basis approaching zero. Even most of those close to the field have given little thought to the attitude of the Revenue Service in its handling of those emblems of American business in the administration of the tax laws. By way of example, take the purchase by the Gillette Company of Paper Mate. Assuming this was a purchase of the assets, a substantial portion of the price was undoubtedly meant to represent the value of the trademark; if the accountants for Gillette are proponents of the theory that trademarks are exhaustible, ${ }^{4}$ then that portion of the purchase price has probably been treated for balance sheet purposes as an asset of diminishing value and, by this date, has been substantially written down. Yet, as will be discussed later, it is clear that the Internal Revenue Service will take a contrary view and may, in addition, contend for allocations of the purchase price not considered by the parties to the transaction. The inconsistency between business accounting and tax accounting may occasion some surprise that more businessmen have not told their lawyers that "they can't do this to me," a reaction usually causing a great outpouring of decisions for us to examine and interpret.

Hampered to some extent by the meagerness of adequate guides, this paper will attempt to examine some of the questions which face the trademark owner and, in passing, to post some red lights for the assistance of those passing along the tax road through the trademark and trade name area. While discussion will be comparatively simple, it is hoped that its major virtue will be to present in a single place an analysis of the major problems which must be taken into account. Unless otherwise indicated, trademark or mark as used herein will include trademarks of all classifications and trade names.

Tax problems in this area may be divided generally into those which relate to the acquisition of the mark and those which relate to its use thereafter. These categories of course overlap to some degree. In addition, the

4 Soper, Certain Accounting and Tax Aspects of Trade Marks, 44 Trade-Mark Rep. 1, 8 (1955). The author says that the accountant generally amortizes these trademark assets, but he does not depreciate them. 
examination of each must imvolve considerations of the created mark apart from the purchased mark and the trademark registrable under section 1 of the Lanham Act ${ }^{5}$ apart from the mark whose registrability requires the acquisition of secondary meaning.

In discussing the tax problems arising in the first-mentioned broad category-that is, the acquisition of the mark-the trademark created by commercial use and development of the creator must be regarded, at least for the moment, separately from that acquired by purchase. The expenses which are incurred in the process of the creation of a mark would appear to be of comparatively minor significance, although in some instances these amounts may be substantial. Speaking from a large accumulation of ignorance on this matter of creation costs, we would suspect that the major expenditures would be for preliminary research and preparation and for the fee or salary of the artist or other individual responsible for the creative effort. Also taken into account should be those amounts which are expended coincidentally with first use, such as fees for registration, incidental expenses and, of course, the fee of counsel. How shall these expenses be handled when the federal income tax return for the year is being prepared? Looking at the rulings of the Commissioner in the somewhat analogous area of copyright, it is apparent that the Commissioner would insist on capitalizing those items. ${ }^{6}$ We shall reserve for the moment the possibility of a different conclusion if section 174 of the 1954 Internal Revenue Code is applicable to some or all of these items.?

Although it may be that in many cases the creative expenditures are so small relatively that a legal contest would be wasteful of both time and money, it is submitted that a plausible argument can be made that these costs, in part at least, should be currently expensed, or perhaps amortized. The costs, other than for artists' fees or similar expenses, are not incident to the acquisition of a piece of property which can be called a capital asset. The creator already has the property, and the activities incident to registration are simply the acquisition of evidence of the existence of the right and should properly fit within the concept of ordinary and necessary expenses. ${ }^{8}$ Of course, there have been a number of decisions holding that costs

560 STAT. 427 (1946), 15 U.S.C. \$ 1051 (1952).

6 U.S. Treas. Reg. 118, § 39.24(a)-2 (1953) ; I.T. 1287, I-1 CUMr. BULI. 28 (1922); 4 MIRRTENS, LAW OF FEDERAI INCOAEE TAXaTTON $\$ 25.31$ (1954).

7 This new section allows the taxpayer to elect whether he will expense or capitalize research and experimental expenditures. If they are capitalized, amortization period of not less than 60 months may be used, starting with the month in which the taxpayer first realizes benefits from the expenditures.

8 It is certainly true that "registration ... neither creates a right nor destroys validly acquired common-law rights of third parties .... They [the registration statutes] confer certain substantive and procedural benefits to trade-mark owners who seek registration for trademarks already validly acquired by them at common-law through priority of adoption 
of quiet title or other actions in defense of, or to perfect title to, property are not expensible, ${ }^{9}$ and these cases have their counter-part in the trademark area. ${ }^{10}$ But these decisions relate specifically to the administrative determination in the regulations that the expense of perfecting title is a capital expense. ${ }^{11}$ Without arguing the validity of this general rule there would appear to be merit in the contention that the expenses of trademark registration are analogous to the expenses of keeping good records in order to make easier the work of the lawyer or accountant, a recognized ordinary and necessary business expense. ${ }^{12}$ In the alternative, the argument might also be urged that these registration costs are analogous to the cost of painting a building, something which keeps the building in an "ordinarily efficient operating condition," for by registration we make more efficient use of the tradeinark by reducing or eliminating a potential cause of annoyance, the infringement; registration does not necessarily add to the life of the mark. Further, it can be argued that even if we are required to regard these expenses as a capital cost, they should be amortizable over the twentyyear registration period, since the right to renew cannot be considered as the equivalent of renewal. ${ }^{13}$

Since this article was prepared, section 177 has been added to the In-

and use." Gitlin and Woodward, Tax Aspects of Patents, Copyrights and Trade-Marks 9 (1954). See Rolley, Inc. v. Younghusband, 204 F.2d 209 (9th Cir. 1953); Griesedieck Brewing Co. v. Peoples Brewing Co., 149 F.2d 1019 (8th Cir. 1945). Registration would not seem to add value to the mark, but it merely improves the owner's substantive and procedural position in respect to the property; at least, this is so if by "value" we mean incoune-producing device regardless of the legal position of the owner. But cf. Juhan M. Livingston, 46 B.T.A. 538 (1942) (cost of Torrens title registration reflected in basis of property).

9 Garrett v. Crenshaw, 196 F.2d 185 (4th Cir. 1952) ; Louisiana Land \& Exploration Co., 7 T.C. 507 (1946), aff'd, 161 F.2d 842 (5th Cir. 1947). The defense of a property right in a patent is an expensible item, if the taxpayer is in the business of exploitation and hicensing. Urquart v. Commissioner, 215 F.2d 17 (3d Cir. 1954). INT. REv. Code of $1954 \$ 177$ allows defense expenses to be treated as deferred expenses amortizable over a period of not less than 60 months as of January $1,1956$.

10 Food Fair of Virginia, Inc., 14 T.C. 1089 (1950) (attorney's fees in suit to defend title or right in trade name not expensible). Cf. Clark Thread Co. v. Commissioner, 100 F.2d 257 (3d Cir. 1938) (payment to cause competitor to cease use of name "Clark" not a business expense but an expense of acquiring capital asset of indeterminate duration). See note 9 sttpra.

11 U.S. Treas. Reg. 118, § 39.24(a)-2(a) (1953) ; U.S. Treas. Reg. 111, § 29.23-15(a) (1952).

12 Rev. Rul. 3732, 1945 CuM. Buxx. 88. Microfilming old newspaper files to unake records more efficient was allowed as ordinary and necessary busmess expense. Trademark registration is actually a means of preserving evidence of ownership and greatly simplifies the counsel's task in any dispute over rights.

13 Some of the language of Duesenberg, Inc. of Delaware, 31 B.T.A. 922 (1934) would appear to lend support to this position. On the renewal point note the imphication in the regulations that the right to renew is not the same as renewal. U.S. Treas. Reg. 118, \$39.23(a)-10 (1953). See also U.S. Treas. Proposed Reg. 1.167(a)-1-4. Section 177 now gives more favorable treatment insofar as amortization is concerned than here suggested but such treatment only applies to expenses subsequent to December 31, 1955. 
ternal Revenue Code. ${ }^{13 a}$ This section provides a new treatment for tax purposes of expenditures of acquisition, protection, expansion, registration or defense of a trademark or trade name. At the election of the taxpayer, amounts incurred or paid after December 31, 1955, for these purposes may be amortized over a period of not less than sixty months. The section does not apply to the purchase price of an acquired trademark or trade name nor to expenses which are not chargeable to capital account. That portion of the following discussion relating to so-called acquisition expenses is, therefore, now pertinent only for years prior to 1956. There is, of course, also the probability that the section will be regarded as precluding the argument that this type of expenditure can be currently expensed; although there still is a possibility as discussed hereinafter that section 174 might be considered applicable.

The use of the word "expansion" in section $177(b)(1)$ raises some additional queries which cannot be answered here. For example, does the word "expansion" mean the use of the trademark in new areas or does it mean the expansion of its use to new products. Further, under the new section are advertising expenses incident to expansion to a new area or to new production use subject to amortization under section 177 or does the restriction in that section to capital account expenditures cover this problem? As we note later in this discussion, the question whether advertising expenses should be currently expensed or capitalized is not entirely free from doubt. In any event, the apparently broad language of the new section will certainly provide some new avenues of future inquiry.

The suggestion of amortization raises for consideration the possibility that under section 174 of the 1954 Code $^{14}$ the costs of creating the trademark may be regarded as "research and experimental expenditures." If they were so regarded, the taxpayer would have the option of adopting a policy of either currently expensing or amortizing the amounts expended for such research over a period of sixty months or more, commencing with the first month in which the taxpayer realizes benefits from the research. In the latest revision of Mertens, the editors somewhat obliquely suggest the possibility that section 174 will apply to trademarks, ${ }^{15}$ but unless the Commissioner or the courts are more liberal than can normally be expected in their construction of this term, the expenses of creating a trademark will be held to fall outside the concept of research expenditures. ${ }^{18}$

\footnotetext{
13a Publ. I. No. 629, 84th Cong., 2d Sess. § 4(a) (June 29, 1956).

14 See note 6 supra.

254 Mertens, Law of Federal Income Taxation $\$ 25.30$ (1954). This is not to say that the editors of that treatise offer much hope for the success of such application.

16 See Alexander, Research and Experimental Expenditures, 10 TAx L. Rev. 549, 552 (1955). The author indicates, referring to the restrictive wording of $\S 174$ and statements made by Commissioner Dunlap of the Internal Revenue Service that the section would not be extend-
} 
Our second tax category relates to purchased trademarks and to those registrable on the principal register under section 1 of the Lanham Act and those the full bloom of which comes only with the acquisition of secondary meaning. ${ }^{17}$ In addition to the initial creation and registration costs which were discussed above, consideration must be given to the constant "vitamin injections" necessary in the case of every trademark, i.e., those expenditures which can be characterized as build-up costs. Generally, a mark of the type which, by reason of section 2 of the Lanham Act, is not registrable on first use has comparatively minor value until it has acquired protectibility under the secondary ineaming doctrine. Jones chooses the name "San Francisco's Better Batter" for his prepared cookie mix. He expends a large sum making that delectable-sounding name known throughout the western United States through newspaper, magazine, radio and television advertising. The expenditures are necessarily for the dual purpose of promoting the present sale of the product and building protectibility. Should these expenditures be regarded as capital or current expense? Would the Commissioner be justified in taking the position that they can be likened to those of the property owner who builds a building on a vacant lot? The regulations provide that expenditures which improve the property and lengthen its life or expand its usefulness must be capitalized in the case of tangible property. ${ }^{18}$ If Jones neglects to make expenditures of this nature, experience has shown that Jones' name, however exotic, will soon disappear from the business world. Although the process of extinction may be slower than in the case of Jones' trade name, it would appear axiomatic that the same result would occur in the case of Coca Cola, Cadillac or Ethyl. The first query we should raise is whether we can logically distinguish between the building of a trademark into nationwide identification and the adding of air conditioning to an office building in Washington, D.C. Perhaps it could be argued that we can differentiate between the expenditures incurred in

ed beyond research and development costs in the experimental or laboratory sense. Trademark and trade name research certainly comes within the terms of $\$ 174(\mathrm{~b})$ which refers to "research and experimental expenditures which are-(C) chargeable to capital account but not chargeable to property of a character which is subject to the allowance under section 167 (relating to allowance for depreciation) ....." As will be pointed out later, trademarks probably are not depreciable. In addition we would suppose that a good share of the effort of developing the mark is the result of experimental or laboratory work directed at testing. Miss Sigrid H. Pederson, counsel for the J. Walter Thompson Company, pointed out the importance of the choice in her address before the Trademarks, Trade Names and Unfair Competition symposium conducted by The School of Law, University of California, April 19, 1956.

17 "Marks although not susceptible of exelusive appropriation because of descriptiveness or other defect, frequently acquire through use a special significance or connection with particular commodities-such marks are said to have acquired a 'secondary meaning' as the designation of the origin or ownership of such goods." AMdur, TRAdE-MARK LAw AND Practice 251 (Lanhain Act ed. 1948).

18 U.S. Treas. Reg. 118, § 39.23 (a) -4 (1953). 
the process of acquiring secondary meaning for the name and those which relate to the mark which is initially protected under the 1946 act, but this dichotomy poses new dilemmas. If we make this differentiation when shall we determine that capitalizing shall stop and expensing shall start? What moment of time is identified as the time of birth of protectibility? What particular printed advertisement, radio or TV commercial shall be given the glory of the achievement of public identification? What about the special problems which would arise because of the varying statutory or judicial rules in the 48 states and foreign countries? ${ }^{19}$ These unanswered, and to some extent unanswerable, queries would certainly give some credence to the idea that the taxing authorities and the trademark owners should be willing and anxious to support a uniform rule for the tax treatment of the advertising expenses of building a trademark.

The courts have not entirely neglected this phase of our problem. The Commissioner and the taxpayer have, in a handful of reported cases, attempted either to obtain allocation of advertising expenses between current expense and capital cost or to attribute the entire amount to one or the other. ${ }^{20}$ Naturally the positions of the parties have not been consistent, each urging the result which would, for the moment, give the most advantageous tax result. The courts, viewing the opposing contentions, have generally held that the task of allocating between current business expense and capital cost of building future values is too difficult and that, absent clear and convincing evidence of the latter, all proper advertising expenditures should be considered an item of current expense. Illustrative of this approach is the decision of the Sixth Circuit in Sheldon $\mathcal{E}$ Co. v. Commis-

\footnotetext{
10 See generally Derenberg, The Problem of Trademark Dilution and The Antidilution Statutes, in this Symposium.

20 Sheldon \& Co. v. Commissioner, 214 F.2d 655 (6th Cir. 1954) (advertising expense capitalized if evidence shows with reasonable certainty the benefits resulting in later years); Meredith Publishing Co. v. Commissioner, 64 F.2d 890 (8th Cir. 1933) (money spent to increase magazine circulation augments capital) ; Three-in-One Oil Co. v. Umited States, $68 \mathrm{Ct.}$ Cl.518, 35 F.2d 987 (1929) (in absence of special proof cannot separate advertising expense to promote sales from expense of building trademark); Umited Profit-Sharing Corp. v. United States, $66 \mathrm{Ct} . \mathrm{Cl} .171$ (1928) (taxpayer allowed to capitalize advertising to procure contracts after originally expensing; Government conceded capital nature); Commercial Nat'I Ins. Co. v. Commissioner, 12 B.T.A. 655 (1928) (cost of promoting, developing and maintaining list of policy holders disallowed in computing gain or loss on sale for lack of evidence with which to make allocation between capital expenditure and deductible busmess expense) ; National Industrial Alcohol Co. v. Commissioner, 7 B.T.A. 1241 (1927), aff'd, 38 F.2d 718 (D.C. Cir. 1936) (no segregation between current and future value of advertising where all originally deducted, the court refusing to segregate for loss purposes); Colonial Ice Cream Co., 7 B.T.A. 154 (1927); Richmond Hosiery Mills Co. v. Commissioner, 6 B.T.A. 1247 (1927), aff'd, 29 F.2d 262 (5th Cir. 1928), cert. denied, 279 U.S. 844 (1929) (taxpayer sought to capitalize cost of advertising campaign to build new name; Commissioner contended expense; court concluded that while such expenses may reach into future, company had originally expensed making segregation too difficult).
} 
sioner. ${ }^{21}$ The company was engaged in the laboratory equipment business, and as a sales device periodically issued catalogs. In 1946 it issued a catalog; the next catalog was being prepared in 1952 when the case was first heard. The question for the court was the deductibility in 1946 of the cost of the catalog, conceded the catalog would be effective for more than a year. The circuit court stated that "the fact that an expenditure produces something that has a useful life extending beyond the taxable year is not the controlling test." 22 The court, following other decisions, held that advertising expense, even though incurred heavily in one year with resulting benefits in future years, was nevertheless a deductible expense for the year in which expended. However, in a few cases involving extraordinary expenditures or a particular accounting segregation, the courts have allocated a portion of the advertising expense to the acquisition of a non-depreciable intangible. ${ }^{23}$

An equitable and administratively feasible rule for advertising expenses would be that they are current expenses, unless there is substantial evidence that the expenditures are not related to current business expense, but rather directed primarily at the creation of some future value. Although the burden should be on the businessman, if the expenses are extraordinary, to show the current need, the burden should be on the taxing authorities to show that the expenditures are extraordinary. Such items as comparative expenditures of similar busmesses, the profit picture and other evidence analogous to what is examined in the "reasonable salary" cases would be pertinent; but it would seem logical that in these matters, resting largely on business judgment, the presumption should favor the position that the businessman is making these expenditures properly to nieet current business needs. ${ }^{24}$

In this area there would appear to be no basis for distinction between the registered and non-registered trademark, for in each case the basic question which must be answered is: Have we added a new floor to the building or are we simply keeping everything in good working order? Increase in value attributable to the fact that the premises are always in fine

21214 F.2d 655 (6th Cir. 1954).

22 Id. at 659. Cf. Consolidated Apparel, 17 T.C. 1570 (1952) (5-year advertising program deductible in first year when paid).

23 X-Pando Corp., 7 T.C. 48 (1946) ; Celn Securities Corp. v. United States, 102 Ct. Cl. 86, 55 F. Supp. 109 (1944).

244 Mertens, Federal Law of Income Taxatton $\$ \S 25.68,25.69$ (1954). The editors express the view that in the reasonable compensation cases the determination is a case by case determination based upon all the circumstances of the particular case; the determination of the taxpayer stands unless it is arbitrary; and the burden of proof, if reasonableness is questioned, is on the taxpayer. But cf. Roth Office Equipment Co. v. Galiagher, 172 F.2d 452 (6th Cir. 1949) (court rejected contention of unreasonableness when Government failed to produce experienced witnesses from the industry). 
shape, and thus attractive to more and better tenants, should not be the basis for an allocation of costs to capital account. ${ }^{25}$ Nor should the fact that the normal expenses of advertising which keep the trademarked product currently acceptable and also help to make that marked product acceptable in the future be the occasion for the allocation of a portion of those expenses to the capital account. The activity of the cigarette manufacturer in emblazoning on billboards, in newspapers and magazines, and im shouting over the radio and television the name of his filtered cigarette is directed mainly at the building of that name as a name forever emblematic of quality. He wants to sell his cigarettes this year, next year and the years thereafter, but there is no method of accurately determining for the current tax year the amount of his advertising expenditure which might possibly relate to the subsequent period; the manufacturer could certainly testify that to conduct his business efficiently this year the expenditures must be made. If we do not adopt the basic presumption here suggested, it is submitted that the administrative difficulties of segregation will continue to be nearly insuperable. Some tendency in the direction of the suggested policy is exhibited in the liberal attitude of the courts in allowing as current expenses expenditures made for the purpose of building goodwill which in most instances would consist of building the trademark.

There is a substantial group of cases in which expenditures have been allowed as current business expense when, at first blush, they would appear to be remote from what we have come to regard as "ordinary and necessary expenses" of the business enterprise. A case in point is the recent decision of the Tax Court in the matter of the Sanitary Farmer Dairy, Inc. ${ }^{28}$ The family owning all the corporate stock of the company were ardent hunters. Over the years they had developed a fine display of trophies which was open to the public, and they had a custom of giving wild-game dinners for their customers. An imaginative and enterprising employee, the advertising manager, suggested to the owners that they undertake an African safari.

25 On the contrary, "ordinary and necessary" expenses, periodically incurred or paid, which tend to keep the property in efficient operating condition are generally deductible, and they obviously add value to the property in the sense that is indicated in the text. See 4 MERTENS, FEDERAL LAW OF INCOME TAXation $\$ \$ 25.09,25.41$ (1954).

2625 T.C. 463, No. 58 (Dec. 1955). See also Rodgers Dairy Co., 14 T.C. 66 (1950) (cost of show horses and dogs allowed as advertising expense notwithstanding Government's contention that such activity was hobby of principal stockholder). Cf. Haverhill Shoe Co., 15 T.C. 517 (1951). In the Haverizill case the court refused to allow expense deduction for the cost of the wedding of the daughter of the majority stockholder even though a large number of customers were among the invited guests. However, even in this case, the court did not reject unequivocally the possibility that weddings, like wild-game hunts, could conceivably be a proper advertising iteu. The presumption suggested in the text above probably should not be apphed to promotional expeuses which were not incurred through the use of normally accepted media. 
After discussion with an advertising agency, it was decided that the president and his wife should make the trip. The trip cost in excess of $\$ 16,800$, about one-fourth of the total advertising expense of the company and onethird of the net income. On their return the hunting dairymen added some choice trophies to their collection and invited a large number of people (customers and potential customers) to see a motion picture of the expedition. The court commented on the extensive publicity given the company, as well as the participants, in connection with the expedition. Despite the efforts of the Commissioner the court, without a qualm, held this to be an "ordinary and necessary expense of the dairy business," remarking that the dairy could not have obtained equal advertising for the same money by normal methods. The amount spent for the safari in the taxable year was allowed as a deduction for that year, though it is obvious that the benefits of the trip will extend over several years. No comment need be made on the extent to which imaginative advertising people might expand this particular version of promotional activity, but the case does illustrate that the concept "ordinary and necessary expense of the dairy business" is not static.

This liberal approach substantially lessens the tax problems for the created trademark, but from past indications such liberality will not be applied to the purchased mark, and in this day of increasing mobility in industrial acquisitions this facet of the problem is of growing importance. Our friend Jones, the cookie batter king, creates in his mind a trademark, converts the idea to concrete form and spends a million dollars advertising that mark. As indicated above, that entire amount will undoubtedly be currently expensed without question or comment. ${ }^{27}$ However, if Jones found instead that he could acquire for a million dollars an already established trademark suitable for his purposes, a mark which would obtain the same market for his product without any additional expenditure, he would not be allowed to expense any portion of the million. This item of expenditure would be unusable for tax purposes so long as he kept the mark, for he would be held to have acquired a capital asset ${ }^{28}$ and a non-depreciable one at that. ${ }^{29}$ Thus, the fact that in each instance a million dollars was spent to

27 Current expensing probably will be allowed where there is no attempt to segregate between current and future benefits and where the taxpayer expenses the item initially. Sce notes 19-23 supra, and related text.

28 The trademark seems clearly to come within the definition in the Code. INT. REv. CodE of 1954, § 1221. See Seattle Brewing \& Malting Co. v. Commissioner, 6 T.C. 856 (1946), aff'd, 165 F.2d 216 (1947), rehearing denied, 166 F.2d 324 (9th. Cir. 1946) ; The Stuart Co., 9 CCH Tax Ct. Mem. 585 (1950), aff'd per curiam, 195 F.2d 176 (9th Cir. 1952) ; Norwich Pharmacal Co., 30 B.T.A. 326 (1934) ; I.T. 2402, VII-1 CuM. BuLL. 94 (1928) ; Clark Thread Co. v. Commissioner, 100 F.2d 257 (3rd Cir. 1938).

29 The non-depreciable character of a mark arises from the assumption that it has an indeterminate perpetual hfe. See Seattle Brewing \& Malting Co. v. Commissioner, 6 T.C. 856 (1946) ; Norwich Pharmacal Co., 30 B.T.A. 326 (1934) ; Leggett \& Platt Spring Bed Mfg. Co., 
achieve an identical result will not serve to bring about an identical tax consequence. By some critics of our tax laws this may be considered as another instance in the tax law administration where form triumphs over substance. It is certainly an illustration of the advantage of the "do-it-yourself" fad. Of course, the purchased mark will have a milkon dollar basis for tax purposes upon sale, but that is small solace to the purchaser whose intent is to use it in perpetuity, or who endeavors to set off its cost against the income which he hopes its million dollar value will bring him.

There is another problem in relation to the purchase of trademarks which should be mentioned briefly before we examine the possibility of depreciating trademarks. This problem arises in instances where there is a purchase of a business whose assets include, among other items, trademarks. Of course, for the purpose of the ultinate tax consequences the purchaser will normally use whatever leverage he can to attribute the maximum value to the depreciable assets and the sinallest portion possible to trademarks, goodwill and other non-depreciable properties. Although the Internal Revenue Service practice generally is to accept the arms' length valuations of the parties, it will not approve valuations which cannot be substantiated by the facts and which are premised primarily on tax considerations. ${ }^{30}$ However, even where the amounts which the negotiators could have designated would have been reasonable, there have been a number of instances where the parties simply ignored any dollar segregation and in the sale agreement priced goodwill at a lump sum without particular value reference to the separate intangibles acquired in the transaction. ${ }^{31}$ This failure must have occurred either because of ignorance on the part of the representative of the purchaser, or because it was anticipated that the trademark and the total goodwill were inseparable in toto. ${ }^{22}$ However, we

18 B.T.A. 1012 (1930). Also Soper, Certain Accounting and Tax Aspects of Trade Marks, 44 Trade-Mark Rep. 1, 5 (1955); Gitldn and Woodward, Tax Aspects of Patents, Copyrights and Trade-Marks 70 (1954); 4 Mertens, Law of Federal Income TaXation 23 (1955).

${ }^{30}$ Courier-Journal Job Printing Co. v. Glenn, 37 F. Supp. 55 (W.D. Ky. 1941), aff'd, 127 F.2d 820 (6th Cir. 1942); Addressograph-Multigraph Corp., 4 CCH Tax Ct. Mem. 147 (1945). In both cases there was no consideration of intangibles during the negotiations, and the court was not satisfied, in either instance, that the taxpayer had proved the existence or value of the intangibles. Note the formula suggested in an early memorandum for application where there is no other adequate evidence. A.R.M. 34, 2 Cus. Burt. 31 (1920). For example of application of the formula, as well as an illustration of the general statement in the text, see Wm. S. Gray, 9 CCH Tax Ct. Mem. 267 (1950) ; McKinney Mfg. Co. v. Commissioner, 10 T.C. 135 (1948).

31 Kraft Foods Co., 21 T.C. 513 (1954) (value of patents in sale transaction reduced from taxpayer's contention, the issue being the depreciation deduction allowable for the patents); D. S. Leick, 7 CCH Tax Ct. Mem. 18 (1949); Marc Eidlitz \& Son, Inc., 18 B.T.A. 187 (1929); Farmers' Grain Co., 1 B.T.A. 605 (1925).

32 Lehn \& Fink Products Corp., 7 T.C. 287 (1946). But see Coca-Cola Bottling Co. v. Coca-Cola Co., 269 Fed. 796 (Del. 1920). There inay be various factors, separate and apart from trademarks, which tend to create goodwill. 4 MERTEns, FEDERAL Law of Ircome TaxaTroN 74 (1942). 
are all aware that in many cases subsequent transactions occur in which there are transfers or dispositions, such as a right of area use of the mark together with the goodwill attached thereto, or abandonment of the mark, in which the basis of the mark, for tax purposes, is of utmost importance. In the absence of a segregation in the original purchase agreement the court will normally examine the evidence produced, which is usually vague after the passage of a long period of time, and make its own segregation, possibly making an allocation to the retained goodwill which is far in excess of the purchaser's own concept of that value. ${ }^{33}$ If the purchaser is basically interested in the mark, or recognizes a value attributable to the mark, he should make the value allocation in the agreement instead of leaving it to the court to make the calculation twenty years later.

Either for good or bad the lines are more defined and the conclusions more certain when we turn to the section of the tax law where many of the trademark cases have arisen, namely depreciation and the related concept of obsolescence. For the first few years of our present income tax history the Internal Revenue authorities allowed obsolescence for assignable goodwill. ${ }^{34}$ However, since 1918 the Commissioner has taken what appears to be an inflexible stand that goodwill and trademarks are intangible assets not subject to exhaustion and, therefore, are non-depreciable. ${ }^{35}$ With the new emphasis in the 1954 Code on accelerated depreciation ${ }^{36}$ and the much more tolerant attitude of the Internal Revenue Service with respect to the taxpayer's choice of the method of depreciation ${ }^{37}$ the effect of the refusal to allow any depreciation of trademarks is accentuated. The position of the

33 See Fox River Paper Corp. v. United States, 65 F. Supp. 605 (E.D. Wis. 1946), aff'd, 165 F.2d 639 (7th Cir. 1948); R. E. Baker, 37 B.T.A. 1135 (1938), affd, 115 F.2d 987 (6th Cir. 1940). Cf. Harlan E. McGregor, 14 CCH Tax Ct. Mem. 897 (1955). Of course, the taxpayer obtains an advantage if he succeeds in his argument that a lesser portion of the purchase price was for goodwill since this means, in effect, that the basis of the acquired tangible assets will be higher and the resulting gain on any subsequent sale lower unless the sale price agreement segregates a large portion of the price to intangibles.

34 T.B.R. 44, 1 CuM. Buxx. 133 (1919); O.D. 298, 1 CuM. Burx. 138 (1919); 21 A.R.M. 34, 2 Cum. Buld. 31 (1920); O.D. 472, 2 Cum. Butr. 141 (1920); A.R.R. 722, I-1 CuMr. BUtL. 169 (1922); A.R.R. 1329, II-1 CUM. BuLL. 99 (1923).

35 T.D. 4055, VI-2 Cuar. Buxx. 63 (1927) ; U.S. Treas. Reg. 103, § 19.23(1)-6 (1952); U.S. Treas. Reg. 111, § 29.23(1)-1 (1952); U.S. Treas. Reg. 118, § 39.23(1)-3 (1953). In the last issued regulation the language specifically denies depreciation of goodwill. Something can be said for distinguishing between goodwill and trademarks and trade names, as suggested above at note 32 supra. See also 4 MerTENs, FEDerat Law of InCOME TAXATIon 191 (1954), where the editors contend that the Tax Court and the Supreme Court have imphed a distinction exists.

36 INT. REv. CODE OF 1954, § 167. Alternative methods of depreciation in the Code allow larger deductions in the early years and smaller deduetions in the later years, i.e., double declining-balance depreciation and sum-of-the-digits depreciation.

37 See, e.g., Rev. Rul. 90, 1953-1 Cum. Burx. 43; Rev. Rul. 91, 1953-1 Cumr. Burx. 44. A close examination of the policy of the Commissioner may be found in 4 MERTEns, Federar LAW OF INCOME TaxaTToN, $\$ \$ 23.31-37 \mathrm{~b}$ (1954). 
Commissioner on the non-depreciable nature of the trademark is based primarily upon the decisions of the Supreme Court in Clark v. Haberle Springs Distillery ${ }^{38}$ and Renziehausen v. Lucas. ${ }^{39}$ The former case related to the attempt to allow for obsolescence of goodwill occasioned by the closing of the distilleries due to the advent of prohibition; the latter was concerned with the effect of the same events on goodwill including trademarks and trade names. As will be shown shortly, there is serious question of the general applicability of these cases; however, they have been cited as authority for the proposition that goodwill and trademarks are per se nondepreciable assets. ${ }^{40}$ There is no possibility of disagreeing with this position, if we concede that for all practical purposes trademarks and goodwill are akin to the "good earth" and are perpetual in existence. However, as a categorical statement this is certainly not defensible.

We can admit that there is great uncertainty as to the life of goodwill or a trademark, but the fact of actual indefinite existence has not been a deterrent to the allowance of depreciation of other properties. For example, a motion picture has an uncertain life, but it does have what we may call an average mortality experience which is "guessable" and on the basis of which depreciation has been and is calculated and allowed. ${ }^{41} \mathrm{It}$ is difficult to say how many trademarks have been adopted in this country. Some have lasted for generations; others have exhausted their entire usefulness within a year or less. This is also true in the case of motion pictures. Some of us will remember that for nearly forty years "Birth of a Nation" was being shown in the theaters. "Gone With the Wind" is now having its third big blow and, despite Vistavision, 3-D, Cinemascope and other innovations, it will probably be viewed by audiences long after most of us have departed for an untrademarked area.

It would seem that the experience with trademarks is sufficient to allow for the calculation of an actuarial fornula with no greater ratio of error than we have experienced in the motion picture industry, or in fact in most other industries. The Internal Revenue Service will accept a fifty-year use-

38280 U.S. 384 (1930).

39280 U.S. 387 (1930); the Haberle Springs and Renziehausen cases had been preceded by numerous decisions to the same effect.

40 Moise v. Burnet, 52 F.2d 1071 (9th Cir. 1931); Hupfel Co. v. Anderson, 51 F.2d 115 (S.D.N.Y.1931) ; Norwich Pharmacal Co., 30 B.T.A. 326 (1934). Cf. Burnet v. National Industrial Alcohol Co., 282 U.S. 646 (1931); Gambrimus Brewery Co. v. Anderson, 282 U.S. 638 (1931). In these two cases the Haberle decision was distinguished on the ground that it was limited to goodwill and should not be expanded to disallow obsolescence of tangibles from impending prohibition. Paul Jones \& Co. v. Lucas, 33 F.2d 907 (W.D. Ky. 1929), aff'd per curiam, 64 F.2d 1016 (6th Cir. 1933).

41 See Cathedral Films, Inc., 5 CCH Tax Ct. Mem. 112 (1946) (estimate of 10-year life in the case of religious films allowed by the court as reasonable); Leona Anderson, $11 \mathrm{CCH}$ Tax Ct. Mem. 384, 386 (1952) (court notes that most motion pictures are amortized on the basis of a two-year life). 
ful life for steel and concrete buildings, although we all know that many of them are full of tenants long after that period has elapsed. One acquaintance of ours is today living in a 175-year old house, the life of which, for depreciation purposes, would have been estimated at 30 years. Even if it were to be urged that some trademarks, such as "Camel" for cigarettes, appear to have perpetual lives, the answer is that depreciation formulas are based on average experience, not individual experience. The determination is not based upon some statistical or scientific analysis of the particular trademark, but it is rather a "guesstimate" premised upon experience with marks of the particular type and in relation to the particular product or industry. In any event, it would seem to be worth the effort for some experts in the field to examine again the possibility of working out and submitting to the Commissioner a formula for the depreciation of the cost of trademarks, whether purchased or created.

Despite the unequivocal attitude of the Commissioner it is suggested that the case law does not offer unquestioned support for his position. The Haberle Springs and Renziehausen cases arose out of the peculiar situation incident to the prohibition law. The Supreme Court decisions appear to be based entirely on this factor. When the former case was in the Second Circuit the court recognized that, upon the evidence of limited duration, goodwill and trademarks were entitled to depreciation in the same manner as other capital assets. ${ }^{42}$ The Supreme Court decided its case upon the premise that "when a business is extinguished as noxious under the Constitution the owners cannot demand partial compensation in the form of abatement of taxes"; ${ }^{43}$ the Court did not discuss the basic language as to the nature of goodwill. Subsequently in Williams v. McGowan ${ }^{44}$ one of our most able and respected jurists, Learned Hand, reaffirmed the holding of the Second Circuit in the Haberle case to the effect that goodwill may be a depreciable intangible. ${ }^{45}$ Perhaps the attractiveness of expensing advertising costs has made the depreciation item of lesser interest, but there is reason to urge re-examination of the question based upon the presentation of the type of

4230 F.2d 219, 221 (2d Cir. 1929).

43 Clarke v. Haberle Crystal Springs Brewing Co., 280 U.S. 384, 385 (1930).

44152 F.2d 570 (2d Cir. 1945).

45 Other cases liave limited the Haberle decision to those instances in whicl a "noxious activity" is involved. Detroit \& Windsor Ferry Co. v. Woodwortl, 115 F.2d 795 (6th Cir. 1940); United States v. Hardy, 74 F.2d 841 (4th Cir. 1935). "Obsolescence of trademarks is not so frequent; but it can happen througll change of language, habits or fashions or through obsolescence of the goods covered by thens. Furthermore, a word or phrase may lose its trademark significance and hence its value as a trademark without passing generally out of use." Grturn and Woodward, Tax Aspects of Patents, Copxrigats and Trade-Marks 74 (1954). As indicated before, the main difficulty in seeking depreciation of a trademark is the presumption that its useful life is indeterminate; proving the value of the trademark also presents some problems. See When Clothing Co., 1 B.T.A. 973 (1925). 
evidence and the formula suggested. With the purchase of trademarks in increasing numbers, the time seems ripe for such re-examination.

\section{Conclusion}

In the last decade of our history we have witnessed an ever increasing attack upon the income tax as a vehicle for the support of our national government. This attack, of course, has been due in part at least to the fact that the income tax has had to bear such a large part of the burden of the world situation. Some of the attacks have been solely political, others emotional, and a few based upon the doctrine of states rights. Although this adversary group has appeared to be in the minority, its effect may well be major. It is impossible to tell how much latent opposition has grown up in relation to the income tax law. If we do not want Poujadism here, those who believe in the basic theory of the progressive income tax cannot fling aside these attacks as inconsequential or crack-pot schemes. One of our ablest authorities, Professor Stanley Surrey, has recently suggested the possibility that our incoune tax law is in grave danger unless we eliminate the inequities inevitably connected with our special tax exemptions. ${ }^{46}$ The writers of this article are in complete agreement with Professor Surrey's views and believe that we inust revise our tax laws to limit these sources of special interest largesse. However, it is not only these special exemptions which cause danger to the future of our system, but it is equally in danger by inconsistent treatment of taxpayers or transactions either by statute or regulation. This is especially true when, although there may be techmical distinctions which brimg about the inconsistent treatment, such distinctions are not apparent to the public. In areas where it is clear that we will continue the mode and manner of tax application, for example in items such as depreciation or busmess expense deductions, a determined effort should be made to evolve logical, consistent rules which will enable what are essentially like transactions to be treated $m$ the same manner. A good rule will encourage the courts to reverse the trend toward excessive hberality in such fields as business expense and will prevent the use of transactions as tax devices instead of the application of proper busmess inethods. Such a reevaluation of the rules is overdue in the trademark area.

It is the behef of the authors of this article that, as yet, there has not been offered a method of raising the necessary revenues to support our national government which approaches the efficiency or logic of the progressive income tax or which is so administratively workable. It can be granted that there is vast room for improvement but it is believed that this is internal to the system and that the adoption of a new system does not con-

40 Surrey, Definitional Problems in Capital Gains Taxation, 69 HARv. L. Rev. 985 (1956). 
stitute improvement per se. When we couple all the advantages of our admittedly defective present statute with the unique role of the individual in the self assessment feature of the act and the nearly universal public acceptance of that role, it would appear that the prime effort should be to smooth out the rough places and fill the chuck holes rather than to tear up the road and try to repave with an untried type of cover. The tax aspects of trademarks offer opportunity for such preventive repair work. 